\title{
PERAN GENDER, PENGAMBILAN KEPUTUSAN, DAN KESEJAHTERAAN KELUARGA DUAL EARNER
}

\author{
Mardiyah Kartini Siswati ${ }^{1 *}$, Herien Puspitawati ${ }^{1}$ \\ ${ }^{1}$ Departemen Ilmu Keluarga dan Konsumen, Fakultas Ekologi Manusia, Institut Pertanian Bogor, \\ Bogor, 16680, Indonesia
}

*) Email: kartinimardiyah@gmail.com

\begin{abstract}
Abstrak
Kemiskinan dapat diakibatkan oleh tuntutan ekonomi yang semakin tinggi sehingga akan berdampak pada tingkat kesejahteraan keluarga. Kondisi tersebut dapat mendorong seorang istri untuk turut serta bekerja di sektor publik. Kesejahteraan keluarga juga dapat dipengaruhi oleh adanya kerja sama antara suami dan istri dalam pembagian peran gender dan pengambilan keputusan. Penelitian ini bertujuan untuk menganalisis peran gender, pengambilan keputusan, dan kesejahteraan keluarga dual earner dengan istri yang memiliki usaha ekonomi mikro di Jakarta. Penelitian ini menggunakan desain cross sectional dengan melibatkan 62 istri yang dipilih secara purposive. Keluarga yang terlibat dalam penelitian ini merupakan tipe keluarga lengkap dengan istri yang bekerja sebagai pelaku usaha ekonomi mikro dan suami bekerja di sektor formal maupun informal. Pengumpulan data dilakukan melalui wawancara dengan menggunakan kuesioner. Analisis data yang digunakan adalah deskriptif, korelasi Pearson, dan regresi linier berganda. Hasil penelitian menunjukkan bahwa capaian keseluruhan variabel peran gender dan pengambilan keputusan berada pada kategori dominan pada salah satu pihak (suami atau istri saja). Kesejahteraan keluarga subjektif maupun objektif secara umum termasuk dalam kategori tinggi. Usia suami dan peran gender berhubungan positif dan signifikan dengan kesejahteraan subjektif keluarga serta kesejahteraan subjektif berhubungan positif dan signifikan dengan kesejahteraan objektif keluarga. Kesejahteraan subjektif keluarga dipengaruhi secara positif signifikan oleh peran gender dalam domain domestik dan pendapatan keluarga.
\end{abstract}

Kata kunci: dual earner, kesejahteraan objektif keluarga, kesejahteraan subjektif keluarga, pengambilan keputusan, peran gender

\section{Gender Roles, Decision Making, and Well-Being of Dual Earner Family}

\begin{abstract}
Poverty can occur due to increasing of economic demands that affect the level of family well-being. It encourages wives to work in the public sector. Family well-being could be influenced by husband and wife cooperation regarding gender roles and decision making. This study aimed to analyze the gender role, decision making, and well-being of dual-earner families who were the wives had micro-enterprises and lived in Jakarta. This study used cross-sectional design and involved 62 families who are selected purposively. The participants were intact families who were the wives had micro-enterprises and the husband worked in formal or informal sectors. Data was collected by an interview using questionnaire. Data were analyzed by descriptive statistic, Pearson correlation, and multiple linear regression. The results showed that the average scores of the overall gender role and decision making in the dominant category on one subject (husband or wife only). The family subjective and objective wellbeing was generally in the high category. The husband's age and gender roles were positively and significantly related to the family subjective well-being, then family subjective well-being was positively and significantly related to the family objective well-being. Moreover, family subjective well-being was significantly positive influenced by domestic domain dimension of gender roles and family income.
\end{abstract}

Keywords: decision making, dual earner, family objective well-being, family subjective well-being, gender roles

\section{PENDAHULUAN}

Data Badan Pusat Statistik (BPS) pada bulan September 2016 menunjukkan bahwa jumlah penduduk miskin di DKI Jakarta mencapai 385,84 ribu orang atau sekitar 3,75 persen.
Jumlah tersebut naik sebesar 1,54 ribu orang selama periode bulan Maret sampai dengan September 2016 (BPS Provinsi DKI Jakarta, 2016). Kemiskinan dapat terjadi karena berbagai hal, salah satunya adalah kebutuhan keluarga yang semakin meningkat, terlebih 
pada keluarga yang tinggal di pusat kota seperti Jakarta. Tingginya tuntutan ekonomi, juga akan meningkatkan jumlah pasangan dual earner, yaitu suami dan istri yang sama-sama bekerja. Hal ini ditandai dengan meningkatnya Tingkat Partisipasi Angkatan Kerja (TPAK) perempuan sebesar 6,26 poin dari 51,85 persen pada Februari 2014 dan menjadi 58,11 persen pada Februari 2015 (BPS Provinsi DKI Jakarta, 2014). Faktor utama yang mendorong istri bekerja adalah kebutuhan ekonomi, di mana pendapatan tunggal dari suami tidak lagi cukup untuk memenuhi kebutuhan hidup keluarga. Selain itu, faktor kedua yang mendorong istri bekerja adalah untuk aktualisasi diri, yaitu mengembangkan keterampilan dan menambah relasi (Lubis \& Syahfitriani, 2007).

Undang-Undang No. 52 Tahun 2009 pasal $48 f$ Tentang Perkembangan Kependudukan dan Pembangunan Keluarga menyebutkan bahwa pembangunan keluarga dapat diwujudkan melalui pembinaan ketahanan dan kesejahteraan keluarga untuk mewujudkan fungsi keluarga yang optimal. Salah satu hal yang dapat dilakukan yaitu dengan cara meningkatkan akses dan peluang terhadap penerimaan informasi dan sumber daya ekonomi melalui usaha mikro keluarga (Puspitawati, 2015). Kementrian Koperasi dan UKM (Usaha Kecil dan Menengah) mengartikan usaha mikro sebagai kegiatan rakyat berskala kecil dan bersifat tradisional serta informal, dalam arti belum terdaftar, belum tercatat, dan belum berbadan hukum. Selain itu, menurut Undang-Undang Republik Indonesia Nomor 20 Tahun 2008 Tentang Usaha Mikro, Kecil, dan Menengah, kriteria usaha mikro yaitu: (1) Memiliki kekayaan bersih paling banyak Rp50.000.000,00 (lima puluh juta rupiah) tidak termasuk tanah dan bangunan tempat usaha; (2) Memiliki hasil penjualan tahunan paling banyak Rp300.000.000,00 (tiga ratus juta rupiah).

Tujuan usaha mikro, kecil, dan menengah adalah untuk menumbuhkan dan mengembangkan usaha dalam rangka membangun perekonomian nasional berdasarkan asas demokrasi ekonomi yang berkeadilan. Melalui usaha mikro, diharapkan dapat menambah pendapatan dan produktivitas keluarga. Data dari Kementrian Koperasi dan UKM (Usaha Kecil dan Menengah) pada tahun 2015 menunjukkan bahwa, dari 52 juta pelaku UKM yang ada di seluruh Indonesia, 60,0 persen usaha dijalankan oleh perempuan. Perempuan yang berwirausaha dapat memberikan dampak positif, yaitu mengurangi angka kemiskinan, menyerap tenaga kerja, dan pemerataan kesejahteraan. Selain itu, perempuan yang memiliki motivasi dan semangat untuk mengembangkan usaha serta berperan aktif dalam pembangunan ekonomi, maka akan meningkatkan pertumbuhan ekonomi bangsa (Munfaqiroh, 2016).

Keluarga dual earner adalah sebuah keluarga yang memiliki sumber pendapatan yang bersifat ganda, yaitu dari istri dan suami. Masalah yang sering terjadi pada keluarga dual earner adalah adanya ketegangan (Lubis \& Syahfitriani, 2007). Ketegangan tersebut dapat muncul karena kurangnya kerjasama antara suami dan istri dalam melakukan pembagian peran gender di dalam keluarga. Sikap peran gender dapat dipengaruhi oleh bagaimana kualitas hubungan dan pembagian kerja di dalam keluarga (Marks, Bun, \& McHale, 2009). Peran gender meliputi perbedaan peran, fungsi, serta tanggung jawab antara laki-laki dan perempuan sebagai hasil kesepakatan atau hasil bentukan dari masyarakat (Puspitawati, 2012). Perempuan yang bekerja diharapkan tidak melepas tanggung jawab di sektor domestik, yaitu sebagai perempuan, sebagai istri, dan mengurus rumah tangga serta tanggung jawabnya di sektor publik, sebagai pekerja (pelaku usaha) (Twenge, Campbell, \& Foster, 2003).

Kesejahteraan keluarga yang berkesetaraan dan berkeadilan gender dapat terwujud melalui kerja sama peran gender yang harmonis di dalam keluarga (Rahmawaty, 2015). Kesejahteraan keluarga juga dipengaruhi oleh adanya kerjasama dalam proses pengambilan keputusan dalam keluarga (Sultana, Hed, \& Leh, 2013). Hal ini didukung oleh penelitian yang dilakukan oleh Kusumo, Sunarti, dan Pranadji (2008) yang menyatakan bahwa semakin baik kerja sama yang dilakukan oleh suami dan istri dalam melakukan pengambilan keputusan, maka semakin tinggi tingkat kesejahteraan di dalam keluarga. Berdasarkan pemaparan tersebut, penelitian ini bertujuan untuk menganalisis hubungan antarvariabel penelitian dan menganalisis variabel yang berpengaruh terhadap kesejahteraan subjektif 
keluarga dual earner usaha mikro ekonomi perempuan di Jakarta.

\section{METODE}

Penelitian ini menggunakan desain crosssectional. Penelitian ini bekerja sama dengan Pemilihan lokasi ini dilakukan secara purposive atas rekomendasi dari pihak LSM Asosiasi Pusat Pengembangan Sumber Daya Wanita (PPSW) Jakarta. Koperasi Flamboyan yang terdapat di daerah Ciracas dan Koperasi Mandiri yang terdapat di daerah Pondok Ranggon. Kedua koperasi tersebut berada di bawah binaan PPSW. Penelitian dilakukan mulai dari bulan Januari hingga Agustus 2017.

Populasi penelitian ini adalah keluarga dual earner yang menjadi anggota koperasi LSM PPSW dan bertempat tinggal di wilayah DKI Jakarta. Penelitian ini melibatkan 62 orang dengan responden adalah istri yang merupakan anggota dari Koperasi Mandiri dan Koperasi Flamboyan binaan LSM PPSW, memiliki usaha ekonomi mikro di Jakarta, dan memiliki suami yang bekerja baik di sektor formal dan informal. Data primer diperoleh melaui wawancara langsung terhadap responden dengan menggunakan alat bantu kuesioner. Data primer ini meliputi karakteristik istri (usia istri, lama pendidikan istri, dan kontribusi ekonomi istri terhadap pendapatan keluarga), karakteristik keluarga (usia suami, lama pendidikan suami, pendapatan keluarga, dan besar keluarga), peran gender, pengambilan keputusan, serta kesejahteraan subjektif dan kesejahteraan objektif keluarga.

Peran gender merupakan kerjasama yang dilakukan dan disepakati oleh suami dan istri dalam hal pembagian kerja pada aktivitas domestik, publik, dan sosial kemasyarakatan. Kuesioner peran gender dalam penelitian ini dimodifikasi oleh peneliti dari Krzaklewska (2014) dan Puspitawati (2015). Peran gender dibagi ke dalam tiga domain, yaitu domestik, publik, dan sosial kemasyarakatan. Kuesioner ini memiliki 29 item pernyataan yang diukur menggunakan skala likert (1-6), yaitu $1=$ suami saja; $2=$ suami dominan; $3=$ suami dan istri setara; 4=istri dominanan; 5=istri saja; $6=$ lainnya dengan nilai Cronbach's alpha sebesar 0,765 .

Pengambilan keputusan dalam penelitian ini didefinisikan sebagai alternatif pilihan yang disepakati oleh suami dan istri terkait anak, kesehatan, ekonomi, strategi memenuhi kebutuhan hidup, serta sosial budaya dan hubungan keluarga. Kuesioner pengambilan keputusan dimodifikasi oleh peneliti dari Martin, Balocnit, dan Venus (2013) dan Puspitawati (2012). Pengambilan keputusan dibagi menjadi lima dimensi, yaitu pengambilan keputusan terkait anak, kesehatan, ekonomi, strategi memenuhi kebutuhan hidup, serta sosial budaya dan hubungan keluarga. Kuesioner ini memiliki 24 item pernyataan yang diukur menggunakan skala likert (1-6), yaitu $1=$ suami saja; $2=$ suami dominan; $3=$ suami dan istri setara; $4=$ =istri dominanan; $5=$ =istri saja; $6=$ lainnya dengan nilai Cronbach's alpha sebesar 0,830 .

Variabel peran gender dan pengambilan keputusan dilakukan recode skor untuk melihat kerjasama gender antara suami dan istri menjadi: $1=$ suami atau istri saja; $2=$ suami atau istri dominan; 3=suami dan istri setara; $0=$ lainnya. Lainnya diberikan skor 0 dikarenakan dalam penelitian ini hanya fokus pada kerjasama gender antara suami dan istri. Skor yang diperoleh dari masing-masing variabel selanjutnya diubah menjadi skor indeks untuk analisis lebih lanjut.

Kesejahteraan keluarga dibagi menjadi dua, yaitu kesejahteraan subjektif keluarga dan kesejahteraan objektif keluarga. Kuesioner kesejahteraan subjektif keluarga dimodifikasi oleh peneliti dari Dublin (2013) dan Puspitawati (2012). Kuesioner ini terdiri atas 19 item pernyataan. Jenis skala yang digunakan adalah skala likert (1-4), yaitu $1=$ sangat tidak puas; $2=$ tidak puas; $3=$ puas; $4=$ =sangat puas dengan nilai Cronbach's alpha sebesar 0,801. Kuesioner untuk mengukur kesejahteraan objektif keluarga dimodifikasi oleh peneliti dari Delhey et.al. (2001). Kuesioner ini terdiri atas 30 item pernyataan. Jenis skala yang digunakan adalah skala likert (0-1), yaitu $0=$ tidak; $1=y a$ dengan nilai Cronbach's alpha sebesar 0,592. Total nilai dari masing-masing variabel yang diperoleh dihitung indeksnya dan dikategorikan berdasarkan cut off point menjadi tiga kategori, yaitu rendah $(0,00-33,3)$, sedang $(33,4-66,7)$, dan tinggi $(66,67-100,00)$.

Data yang diperoleh diolah dan dianalisis menggunakan analisis deskriptif dan inferensial. Analisis deskriptif adalah analisis yang digunakan untuk mengidentifikasi 
karakteristik keluarga, peran gender, pengambilan keputusan, kesejahteraan subjektif dan kesejahteraan objektif keluarga. Sementara itu, analisis inferensial yang digunakan dalam penelitian ini adalah analisis regresi linier berganda, yaitu untuk menganalisis pengaruh karakteristik keluarga, peran gender, dan pengambilan keputusan terhadap kesejahteraan subjektif keluargadual earner.

\section{HASIL}

\section{Karakteristik Istri dan Keluarga}

Persentase terbesar istri $(77,4 \%)$ dan suami $(67,7 \%)$ berada pada kategori usia dewasa madya menurut Hurlock (1999), yang mana usia dewasa madya berada pada rentang usia antara 41-60 tahun dengan rata-rata usia adalah 47,26 tahun (istri) dan 50,85 tahun (suami). Persentase terbesar pendidikan istri $(35,5 \%)$ adalah pada tingkat SMA dengan lama pendidikan antara 10-12 tahun. Persentase terbesar pendidikan suami $(54,8 \%)$ berada pada jenjang SMA (10-12 tahun). Ratarata lama pendidikan istri dan suami tidak terlalu jauh berbeda. Rata-rata lama pendidikan istri adalah 9,15 tahun, sedangkan rata-rata lama pendidikan suami adalah 10,45 tahun, artinya bahwa lama pendidikan tersebut baik suami maupun istri setara dengan tamat SMP. Besar keluarga diukur berdasarkan jumlah anggota di dalam keluarga. Berdasarkan besar keluarga, lebih dari separuh $(69,4 \%)$ keluarga istri merupakan tipe keluarga kecil (jumlah anggota keluarga $\leq 4$ orang) dengan rata-rata jumlah anggota keluarga sebanyak empat orang. Hal ini berarti keluarga tersebut memiliki dua orang anak. Jumlah minimal dalam keluarga yaitu sebanyak dua orang (hanya suami dan istri saja) dan paling banyak adalah tujuh orang atau memiliki lima orang anak. Rata-rata pendapatan keluarga sebesar Rp7.515.161,00 yang dapat dikatakan bahwa penghasilan keluarga sudah berada di atas garis Upah Minimum Provinsi (UMP) DKI Jakarta tahun 2016, yaitu sebesar Rp3.100.000,00. Besarnya kontribusi istri terhadap pendapatan keluarga dihitung dengan cara membagi pendapatan istri dari hasil usaha (Rp/bulan) dengan pendapatan keluarga (Rp/bulan) kemudian dikalikan dengan 100 persen. Persentase terbanyak $(43,5 \%)$ pendapatan istri dari hasil usahanya berkontribusi sebesar 81-100 persen terhadap pendapatan keluarga. Berbagai macam bentuk usaha mikro yang dilakukan oleh istri diantaranya adalah penjahit, toko kelontong, warung makan, kerajinan tangan, pedagang, dan lain-lain.

\section{Peran Gender Suami dan Istri}

Pada penelitian ini peran gender dikategorikan ke dalam tiga tingkatan, yaitu: 1) kerja sama yang hanya dilakukan oleh salah satu pihak, yaitu suami saja atau istri saja, artinya baik suami dan atau istri kurang melakukan kerja sama dalam aktivitas domestik, publik, maupun sosial kemasyarakatan, misalnya membersihkan rumah hanya dilakukan oleh istri dan yang melakukan gotong-royong di lingkungan rumah hanya dilakukan oleh suami; 2) dominan di salah satu pihak artinya terdapat kerja sama antara suami dan istri, namun masih ada dominasi di salah satu pihak, misalnya suami dan istri saling bekerja sama dalam mengasuh anak, namun istri lebih dominan; 3) seimbang artinya suami dan istri saling bekerjasama satu sama lain, yaitu tidak ada salah satu pihak manapun yang diberatkan, misalnya suami dan istri samasama turut aktif dalam membersihkan rumah, pendidikan dan kesehatan anak, dan kegiatan di masyarakat.

Tabel 1 Sebaran contoh berdasarkan peran gender serta nilai minimum, maksimum, rata-rata, dan standar deviasi

\begin{tabular}{|c|c|c|c|c|c|c|c|c|}
\hline \multirow[t]{2}{*}{ Dimensi } & \multicolumn{2}{|c|}{$\begin{array}{c}\text { Salah satu pihak } \\
\text { (suami/istri saja) } \\
(\leq 33,3)\end{array}$} & \multicolumn{2}{|c|}{$\begin{array}{c}\text { Dominan salah satu } \\
\text { pihak (suami/istri } \\
\text { dominan) } \\
(33,4-66,7)\end{array}$} & \multicolumn{2}{|c|}{$\begin{array}{c}\text { Seimbang } \\
\text { (suami dan istri) } \\
(>66,7)\end{array}$} & \multirow[t]{2}{*}{ Min-Maks } & \multirow[t]{2}{*}{$\begin{array}{l}\text { Rata- } \\
\text { rata } \pm S t d e v\end{array}$} \\
\hline & $\mathrm{n}$ & $\%$ & $\mathrm{n}$ & & & $\%$ & & \\
\hline Domestik & 6 & 9,7 & 52 & & & 6,5 & $15,8-82,5$ & $49,32 \pm 12,70$ \\
\hline Publik & 15 & 24,2 & 36 & 58,1 & 11 & 17,7 & $8,3-91,7$ & $51,08 \pm 18,69$ \\
\hline $\begin{array}{l}\text { Sosial } \\
\text { kemasyarakatan }\end{array}$ & 3 & 4,8 & 21 & 33,9 & 38 & 61,3 & $5,6-100$ & $74,10 \pm 19,97$ \\
\hline Total & 1 & 1,6 & 53 & 85,5 & 8 & 12,9 & $12,6-86,2$ & $54,69 \pm 11,75$ \\
\hline
\end{tabular}


Tabel 2 Sebaran contoh berdasarkan pengambilan keputusan serta nilai minimum, maksimum, ratarata, dan standar deviasi

\begin{tabular}{|c|c|c|c|c|c|c|c|c|}
\hline \multirow{3}{*}{ Dimensi } & \multicolumn{6}{|c|}{ Kategori } & \multirow{3}{*}{ Min-Maks } & \multirow{3}{*}{$\begin{array}{c}\text { Rata- } \\
\text { rata } \pm S t d e v\end{array}$} \\
\hline & \multicolumn{2}{|c|}{$\begin{array}{c}\text { Salah satu pihak } \\
\text { (suami/istri saja) } \\
(\leq 33,3)\end{array}$} & \multicolumn{2}{|c|}{$\begin{array}{l}\text { Dominan salah satu } \\
\text { pihak (suami/istri } \\
\text { dominan) } \\
(33,4-66,7)\end{array}$} & \multicolumn{2}{|c|}{$\begin{array}{l}\text { Seimbang } \\
\text { (suami dan } \\
\text { istri) } \\
(>66,7)\end{array}$} & & \\
\hline & $\mathrm{n}$ & $\%$ & $\mathrm{n}$ & $\%$ & $n$ & $\%$ & & \\
\hline Anak & 13 & 21,0 & 23 & 37,1 & 26 & 41,9 & $0,0-100,0$ & $61,96 \pm 27,27$ \\
\hline Kesehatan & 21 & 33,9 & 16 & 25,8 & 25 & 40,3 & $0,0-100,0$ & $62,72 \pm 30,39$ \\
\hline Ekonomi & 2 & 3,2 & 41 & 66,1 & 19 & 30,6 & $33,3-94,4$ & $61,11 \pm 16,13$ \\
\hline $\begin{array}{l}\text { Strategi memenuhi } \\
\text { kebutuhan hidup }\end{array}$ & 7 & 11,3 & 30 & 48,4 & 25 & 40,3 & $29,2-100,0$ & $62,84 \pm 18,06$ \\
\hline $\begin{array}{l}\text { Sosial budaya dan } \\
\text { hubungan keluarga }\end{array}$ & 14 & 22,6 & 18 & 29,0 & 30 & 48,4 & $22,2-100,0$ & $64,34 \pm 22,69$ \\
\hline Total & 3 & 4,8 & 35 & 56,5 & 24 & 38,7 & $26,4-90,3$ & $62,43 \pm 15,00$ \\
\hline
\end{tabular}

Kerja sama peran gender antara suami-istri paling rendah (6,5\%) yaitu pada aktivitas domestik. Kerja sama yang paling seimbang, yaitu pada aktivitas sosial kemasyarakatan dengan persentase sebesar 61,3 persen. Rata-rata peran gender dalam keluarga masih didominasi oleh salah satu pihak, hal ini terjadi karena istri cenderung lebih banyak berperan dalam aktivitas domestik (Tabel 1). Kerja sama antara suami dan istri pada aktivitas domestik dilakukan secara seimbang ketika merawat anak yang sakit dan merencanakan pendidikan anak. Pada perencanaan perbaikan rumah dan terkait siapa yang memperbaiki rumah ketika rusak suami lebih dominan berperan. Selanjutnya, kerja sama peran dalam membersihkan rumah, mengasuh anak, memasak, dan mengelola keuangan keluarga cenderung hanya dilakukan oleh istri.

Kerja sama peran gender pada aktivitas publik dilakukan secara seimbang oleh suami dan istri dalam bekerja mencari nafkah untuk memenuhi kebutuhan sehari-hari. Hal ini dikarenakan pada penelitian ini dilakukan pada keluarga dual earner. Kemudian, istri lebih dominan dalam mencari informasi untuk mengembangkan keterampilan, memilih untuk tidak bekerja di saat anak sakit, dan meminjam uang untuk keperluan keluarga. Pada aktivitas sosial kemasyarakatan, kerja sama peran gender cenderung hanya dilakukan oleh suami pada saat kerja bakti di lingkungan rumah. Adapun kegiatan yang dilakukan secara bersama-sama oleh suami dan istri dalam mengikuti pertemuan RT/RW, tolongmenolong, berpartisipasi dalam kegiatan masyarakat, kegiatan keagamaan, serta kegiatan sosial.

\section{Pengambilan Keputusan Suami dan Istri}

Variabel pengambilan keputusan dalam penelitian ini terkait bagaimana kerja sama gender yang dilakukan oleh suami dan istri dalam memilih alternatif pilihan untuk mengambil suatu keputusan. Hasil analisis variabel pengambilan keputusan ditunjukkan pada Tabel 2. Rata-rata pengambilan keputusan yang dilakukan oleh suami dan istri masih didominasi oleh salah satu pihak $(62,4 \%)$. Ketika mengambil keputusan yang terkait dengan anak $(41,9 \%)$, kesehatan $(40,3 \%)$, serta sosial budaya dan hubungan keluarga $(48,4 \%)$ suami dan istri mengambil keputusan secara bersama-sama. Pengambilan keputusan yang dilakukan secara bersama-sama terkait dengan anak yaitu, jumlah anak yang ingin dimiliki, cara mendidik anak, dan menentukan jenjang pendidikan anak. Kemudian yang terkait dengan kesehatan yaitu, menentukan tempat berobat, memiliki ide untuk menunda pengobatan jika ada anggota keluarga yang sakit, dan menentukan jenis pengobatan yang dilakukan. Selanjutnya, terkait dengan sosial budaya dan hubungan keluarga yaitu, siapa kerabat dan teman yang akan dikunjungi.

Terdapat cara berbeda dalam melakukan pengambilan keputusan yang terkait dengan ekonomi $(66,1 \%)$ seperti menentukan makanan yang akan dikonsumsi keluarga, membuat prioritas kebutuhan yang akan dibeli, serta mengatur penggunaan uang istri dan suami serta strategi memenuhi kebutuhan hidup $(48,4 \%)$ seperti, menabung dan siapa yang menyuruh istri bekerja masih terdapat dominasi di salah satu pihak, yaitu istri. Hal 
tersebut diduga karena suami menyerahkan dan mempercayakan sepenuhnya keputusan kepada istri untuk mengelola keuangan dan kebutuhan hidup keluarga.

\section{Kesejahteraan Keluarga}

Kesejahteraan keluarga adalah kepuasan, kemakmuran, dan kualitas hidup keluarga yang diukur berdasarkan dimensi kesejahteraan subjektif dan objektif (Qoyyimah \& Wahini, 2016). Kesejahteraan subjektif dalam penelitian ini dikaitkan dengan perasaan puas yang dirasakan contoh atau rasa syukurnya terhadap kondisi yang dialami oleh keluarga dan materi yang diperolehnya, sedangkan kesejahteraan objektif adalah keadaan aktual yang terjadi dalam kehidupan contoh yang terlihat secara fisik baik secara materi maupun non materi. Berdasarkan hasil penelitian setengah $(50,0 \%)$ keluarga contoh termasuk dalam kategori sedang dan tinggi pada kesejahteraan subjektif keluarga. Artinya, contoh sudah merasa cukup puas atau bersyukur terhadap kehidupan keluarganya dan materi yang diperolehnya. Pada kesejahteraan objektif keluarga, lebih dari setengah $(62,9 \%)$ keluarga contoh termasuk kategori tinggi. Artinya, kebutuhan keluarga dari sisi materi maupun non materi secara aktual sudah terpenuhi. Kemudian, baik kesejahteraan subjektif maupun objektif, tidak ada keluarga contoh yang termasuk dalam kategori rendah.

Penelitian ini menggunakan analisis tipologi untuk melihat tipe keluarga contoh berdasarkan kategori kesejahteraan subjektif keluarga dan kesejahteraan objektif keluarga. Tipologi kesejahteraan subjektif keluarga dengan kesejahteraan objektif keluarga di lihat berdasarkan sebaran kategori kesejahteraan subjektif keluarga dengan kesejahteraan objektif keluarga, yaitu kesejahteraan subjektif keluarga rendah-sedang (R-S) dan kesejahteraan subjektif keluarga tinggi $(T)$ dengan kesejahteraan objektif keluarga rendah-sedang (R-S) dan kesejahteraan objektif keluarga tinggi (T). Garis vertikal merupakan kesejahteraan objektif keluarga dengan ketentuan semakin ke atas maka kesejahteraan objektif keluarga akan semakin tinggi. Sedangkan garis horizontal merupakan kesejahteraan subjektif dengan ketentuan semakin ke kanan kesejahteraan subjektif keluarga diartikan semakin tinggi (Gambar 1).
Tabel 3 Sebaran contoh berdasarkan kesejahteraan keluarga serta nilai minimum, maksimum, rata-rata, dan standar deviasi

\begin{tabular}{lcccc}
\hline \multicolumn{1}{c}{ Kategori } & \multicolumn{2}{c}{ Subjektif } & \multicolumn{2}{c}{ Objektif } \\
& $\mathrm{n}$ & $\%$ & $\mathrm{n}$ & $\%$ \\
\hline $\begin{array}{l}\text { Rendah } \\
(\leq 33,3)\end{array}$ & 0 & 0,0 & & \\
$\begin{array}{l}\text { Sedang } \\
(33,4-66,7)\end{array}$ & 31 & 50,0 & 23 & 37,1 \\
$\begin{array}{l}\text { Tinggi } \\
(>66,7)\end{array}$ & 31 & 50,0 & 39 & 62,9 \\
\hline $\begin{array}{l}\text { Min-Maks } \\
\text { Rata-rata } \pm \text { SD }\end{array}$ & $\begin{array}{c}45,6-94,7 \\
67,94 \pm 9,98\end{array}$ & $\begin{array}{c}36,7-90,0 \\
71,13 \pm 11,36\end{array}$ \\
\hline
\end{tabular}

Tipe dalam tipologi ini dibagi menjadi empat tipe, yaitu tipologi tipe I, tipe II, tipe III, dan tipe IV. Tipologi tipe I menggambarkan bahwa kesejahteraan subjektif keluarga yang rendah sedangkan kesejahteraan objektif keluarganya tinggi. Hal ini menunjukkan bahwa menurut persepsi dirinya, contoh merasa tidak puas atau bahagia terhadap kehidupan keluarganya saat ini, namun keadaan aktual yang dialami dan materi yang dimiliki keluarga sudah terpenuhi. Tipologi tipe II merupakan tipe dengan persentase terbesar, yaitu sebanyak 37,1 persen. Tipe tersebut dapat menggambarkan contoh merasa puas dengan kondisi kehidupan keluarga menurut persepsi dirinya dan keadaan aktual yang dialami/materi yang dimiliki keluarga sudah terpenuhi. Hal tersebut menandakan bahwa, kehidupan keluarga yang dijalani contoh sudah tergolong sejahtera baik secara subjektif maupun objektif.

Y (Kesejahteraan objektif)

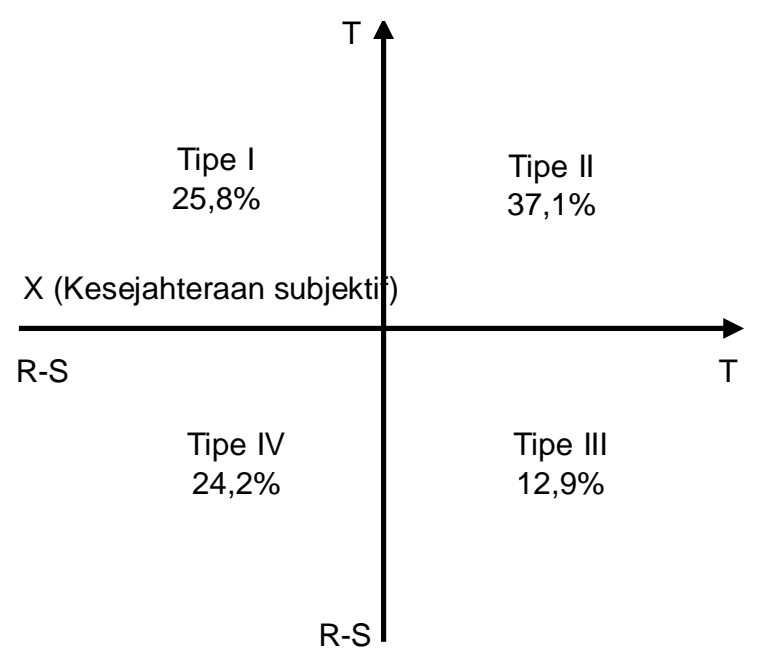

Gambar 1 Grafik analisis tipologi kesejahteraan subjektf keluarga dengan kesejahteraan objektif keluarga 
Selanjutnya, tipologi tipe III menggambarkan bahwa kesejahteraan subjektif keluarga yang tinggi dan kesejahteraan objektif keluarga yang rendah. Contoh yang berada pada tipe ini cenderung tidak dapat memenuhi semua kebutuhan keluarganya, namun tetap merasa bahagia dengan kehidupan yang dijalani saat ini. Terakhir, tipologi tipe IV menggambarkan bahwa kesejahteraan subjektif keluarga rendah dan kesejahteraan objektif keluarga juga rendah. Artinya, contoh yang berada pada tipe ini memiliki keadaan ekonomi yang kekurangan dan tidak pula merasakan kebahagiaan dalam hidupnya.

\section{Hubungan Karakteristik Keluarga, Peran Gender, dan Pengambilan Keputusan dengan Kesejahteraan Keluarga}

Hasil uji hubungan pada Tabel 4 menunjukkan bahwa usia istri mempunyai hubungan negatif yang signifikan dengan pengambilan keputusan. Artinya, semakin matang usia istri, maka kerjasama dalam melakukan pengambilan keputusan semakin menurun. Sementara itu, usia suami mempunyai hubungan positif yang signifikan dengan kesejahteraan subjektif. Artinya, semakin matang usia suami, maka istri merasa semakin bahagia hidupnya. Selanjutnya, pendidikan istri dan suami memiliki hubungan positif yang signifikan dengan peran gender dan pengambilan keputusan. Artinya, semakin lama pendidikan yang ditempuh oleh suami dan istri, maka semakin terjalinnya kerjasama yang harmoni pada pembagian peran gender dan pengambilan keputusan di dalam keluarga.
Pendapatan keluarga mempunyai hubungan negatif yang signifikan dengan pengambilan keputusan. Artinya, semakin besar pendapatan keluarga maka pengambilan keputusan di dalam keluarga cenderung dilakukan secara dominan di salah satu pihak antara istri atau suami. Selanjutnya, kontribusi ekonomi istri terhadap pendapatan keluarga memiliki hubungan negatif yang signifikan terhadap pengambilan keputusan. Hal ini berarti bahwa, semakin besar kontribusi yang diberikan istri terhadap pendapatan keluarga, maka dalam melakukan pengambilan keputusan antara suami dan istri cenderung didominasi oleh salah satu pihak, baik dominan suami atau dominan istri.

Hasil analisis juga menunjukkan adanya hubungan positif yang signifikan antara peran gender dengan pengambilan keputusan. Artinya, jika suami dan istri dapat berbagi peran dengan baik di dalam keluarga, maka dalam mengambil keputusan cenderung dilakukan secara seimbang oleh suami dan istri. Kemudian, peran gender juga mempunyai hubungan positif yang signifikan dengan kesejahteraan subjektif keluarga. Artinya, semakin baik kerjasama yang dilakukan antara suami dan istri dalam melakukan pembagian peran, maka istri merasa semakin bahagia hidupnya. Kesejahteraan subjektif mempunyai hubungan positif yang signifikan dengan kesejahteraan objektif. Hal ini menunjukkan bahwa semakin puas atau bahagia seorang istri dengan keadaan hidupnya, maka kondisi kehidupan aktualnya juga semakin sejahtera (Tabel 4).

Tabel 4 Koefisien korelasi karakteristik keluarga dengan peran gender, pengambilan keputusan, dan kesejahteraan keluarga

\begin{tabular}{|c|c|c|c|c|}
\hline Variabel & $\begin{array}{l}\text { Peran } \\
\text { Gender }\end{array}$ & $\begin{array}{l}\text { Pengambilan } \\
\text { Keputusan }\end{array}$ & $\begin{array}{c}\text { Kesejahteraan } \\
\text { Subjektif Keluarga }\end{array}$ & $\begin{array}{c}\text { Kesejahteraan } \\
\text { Objektif Keluarga }\end{array}$ \\
\hline Usia istri & $-0,066$ & $-0,265^{*}$ & 0,173 & 0,067 \\
\hline Usia suami & 0,013 & $-0,246$ & $0,303^{*}$ & 0,145 \\
\hline Pendidikan istri & $0,306^{*}$ & $0,435^{\star *}$ & $-0,004$ & 0,101 \\
\hline Pendidikan suami & $0,358^{* *}$ & $0,297^{*}$ & $-0,032$ & 0,117 \\
\hline Pendapatan keluarga & $-0,105$ & $-0,277^{*}$ & 0,242 & 0,187 \\
\hline $\begin{array}{l}\text { Kontribusi ekonomi istri } \\
\text { terhadap pendapatan keluarga }\end{array}$ & $-0,232$ & $-0,398^{* *}$ & 0,209 & 0,018 \\
\hline Besar keluarga & 0,029 & 0,045 & $-0,085$ & 0,034 \\
\hline Peran gender & 1 & $0,615^{\star *}$ & $0,261^{*}$ & 0,116 \\
\hline Pengambilan keputusan & & 1 & 0,206 & 0,039 \\
\hline $\begin{array}{l}\text { Kesejahteraan subjektif } \\
\text { keluarga } \\
\text { Kesejahteraan objektif } \\
\text { keluarga }\end{array}$ & & & 1 & $0,416^{\star *}$ \\
\hline
\end{tabular}


Tabel 5 Hasil uji regresi karakteristik keluarga, peran gender, dan pengambilan keputusan terhadap kesejahteraan subjektif keluarga

\begin{tabular}{|c|c|c|c|}
\hline Variabel & $\begin{array}{c}\text { B } \\
\text { (Tidak Terstandardisasi) }\end{array}$ & $\begin{array}{c}\beta \\
\text { (Terstandardisasi) }\end{array}$ & Sign. \\
\hline Konstanta & 53,136 & & 0,000 \\
\hline Usia istri (tahun) & 0,175 & 0,155 & 0,280 \\
\hline Pendidikan istri (tahun) & $-0,288$ & $-0,109$ & 0,454 \\
\hline Pendapatan keluarga (rupiah/bulan) & $5,953 \mathrm{E}-7$ & 0,380 & $0,004^{\star *}$ \\
\hline Besar keluarga (orang) & $-2,061$ & $-0,224$ & 0,098 \\
\hline \multicolumn{4}{|l|}{ Peran gender } \\
\hline Domestik (indeks) & 0,281 & 0,358 & $0,034^{*}$ \\
\hline Publik (indeks) & $-0,113$ & $-0,212$ & 0,108 \\
\hline Sosial kemasyarakatan (indeks) & $-0,026$ & $-0,051$ & 0,705 \\
\hline \multicolumn{4}{|l|}{ Pengambilan keputusan } \\
\hline Anak (indeks) & 0,049 & 0,134 & 0,380 \\
\hline Kesehatan (indeks) & 0,097 & 0,294 & 0,054 \\
\hline Ekonomi (indeks) & $-0,090$ & $-0,146$ & 0,340 \\
\hline $\begin{array}{l}\text { Strategi memenuhi kebutuhan } \\
\text { hidup (indeks) }\end{array}$ & 0,107 & 0,194 & 0,257 \\
\hline $\begin{array}{l}\text { Sosial budaya dan hubungan } \\
\text { keluarga (indeks) }\end{array}$ & $-0,053$ & $-0,120$ & 0435 \\
\hline $\mathrm{F}$ & & 2,285 & \\
\hline Sig. & & 0,021 & \\
\hline $\mathrm{R}$ & & 0,599 & \\
\hline Adjusted R Square & & 0,202 & \\
\hline
\end{tabular}

Pengaruh Karakteristik Keluarga, Peran Gender, dan Pengambilan Keputusan terhadap Kesejahteraan Subjektif Keluarga

Hasil uji analisis regresi menunjukkan nilai Adjusted $R$ Square sebesar 0,202 . Hasil ini berarti bahwa model ini mampu menjelaskan pengaruh karakteristik keluarga, peran gender, dan pengambilan keputusan terhadap kesejahteraan subjektif keluarga sebesar 20,2 persen. Sementara, sisanya sebanyak 79,8 persen dipengaruhi variabel lain yag tidak terdapat dalam model. Hasil analisis juga menunjukkan bahwa pendapatan keluarga memiliki pengaruh positif dan signifikan terhadap kesejahteraan subjektif keluarga $\left(B=5,953 E^{-7}, \quad p<0,01\right)$. Hal ini menunjukkan bahwa setiap peningkatan pendapatan keluarga, menyebabkan meningkatnya kesejahteraan subjektif keluarga. Contoh dengan pendapatan keluarga yang tinggi akan merasa lebih puas atau bahagia hidupnya. Peran gender pada domain domestik mempunyai pengaruh positif dan signifikan terhadap kesejahteraan subjektif keluarga $(B=0,278, p<0,05)$. Hal ini menunjukkan bahwa contoh yang saling bekerjasama pada domain domestik, akan merasa lebih sejahtera hidupnya. Hal ini didukung oleh penelitian sebelumnya yang dilakukan oleh Puspitawati, Herawati, dan Sarma (2010) bahwa tingkat kesejahteraan subjektif dipengaruhi secara nyata dari kerjasama yang dilakukan oleh suami dan istri. Hasil analisis pengaruh karakteristik keluarga, peran gender, dan pengambilan keputusan terhadap kesejahteraan subjektif keluarga disajikan pada Tabel 5 .

\section{PEMBAHASAN}

Pendekatan teori yang digunakan dalam penelitian ini adalah struktural fungsional. Menurut Megawangi (2014) menyatakan bahwa teori struktural fungsional digunakan untuk menganalisis peran setiap anggota keluarga serta mengakui adanya keragaman dalam kehidupan sosial, keragaman tersebut nantinya akan membuat suatu struktur dalam masyarakat dan mengakui kebenaran adanya pembagian tugas. Teori struktural-fungsional dalam melihat sebuah sistem dapat diterapkan dalam berbagai situasi. Sebuah sistem dapat berbentuk apa saja; keluarga, kelompok, organisasi, klub-klub sosial, dan lain-lain. Menurut Puspitawati (2012) menyebutkan bahwa salah satu aspek penting dari perspektif teori struktural fungsional adalah setiap 
keluarga yang sehat terdapat pembagian peran/fungsi keluarga yang jelas, fungsi tersebut terpola dalam struktur hirarkis yang harmonis, dan adanya komitmen terhadap pelaksanaan peran/fungsi tersebut.

Peran gender pada penelitian ini dibagi ke dalam tiga domain, yaitu domestik, publik, dan sosial kemasyarakatan. Domestik terkait dengan kerja sama peran gender antara suami-istri pada aktivitas di dalam rumah dan sebaliknya publik serta sosial kemasyarakatan terkait dengan kerja sama peran gender antara suami dan istri pada aktivitas di luar rumah. Hal yang membedakan keduanya, yaitu publik terkait pada pekerjaan yang menghasilkan uang atau barang, sedangkan sosial kemasyarakatan terkait pada pekerjaan yang tidak dibayar atau bersifat sukarela.

Hasil menunjukkan bahwa capaian kerja sama peran gender antara suami dan istri paling rendah yaitu pada aktivitas domestik. Artinya ada salah satu pihak yang dibebankan lebih besar untuk mengerjakan tugas di rumah, dalam hal ini yaitu istri. Hal ini sejalan dengan penelitian yang dilakukan Far (2012) menyatakan bahwa konstruksi patriakat memposisikan istri pada sektor domestik, sehingga mengakibatkan istri mencurahkan waktu lebih banyak pada aktivitas domestik. Hasil penelitian dari Hikmah, Yulisti, dan Nasution (2009) juga menyebutkan bahwa pola pembagian kerja dan curahan waktu dalam aktivitas domestik didominasi oleh perempuan (istri), sedangkan laki-laki (suami) hanya sebagai tenaga pembantu saja.

Pengambilan keputusan yang dilakukan antara suami dan istri dapat dipengaruhi oleh kematangan emosi dan self-eficacy (Peilow \& Nursalim, 2013). Hasil penelitian menunjukkan bahwa pengambilan keputusan yang terkait dengan anak, kesehatan, serta sosial budaya dan hubungan keluarga sudah dilakukan secara seimbang oleh suami dan istri, artinya suami dan istri saling berdiskusi sehingga dihasilkan keputusan yang sepakat diambil secara bersama-sama. Akan tetapi, pada dimensi ekonomi dan strategi memenuhi kebutuhan hidup masih terdapat dominasi pada salah satu pihak antara istri atau suami. Hal ini sejalan dengan penelitian yang dilakukan oleh Puspitawati, Herawati, dan Sarma (2010) menyebutkan bahwa pengambilan keputusan dan pelaksanaan dalam aspek pendidikan dan kesehatan didominasi keputusan bersama antara suami dan istri, sedangkan pengambilan keputusan seorang istri lebih dominan pada kegiatan mengatur keuangan keluarga dan membuat prioritas kebutuhan (Puspitawati, Herawati, \& Sarma, 2010; Kusmayadi, 2017). Secara keseluruhan, dalam melakukan pengambilan keputusan masih terdapat dominasi di salah satu pihak antara suami dan istri.

Teori Subjective Quality of Live (SQL) oleh Dublin (2013) mengatakan bahwa, kesejahteraan subjektif adalah bagaimana cara seseorang mempersepsikan kualitas hidupnya di dalam keluarga, sedangkan untuk menjelaskan kesejahteraan objektif, peneliti mengacu pada konsep The Euromodule Instrument oleh Delhey (2001) yang menyatakan bahwa, kesejahteraan pada level individu dilihat dari kondisi kehidupannya (pendapatan) dan pada level sosial dilihat dari kualitas sosialnya (distribusi pendapatan). Hasil penelitian ini menunjukkan bahwa istri sudah merasa puas dengan kehidupan keluarganya saat ini, sehingga fungsi di dalam keluarga tidak terganggu. Hal ini dibuktikan oleh terjalinnya kerjasama yang baik antar anggota keluarga dalam hal pembagian peran gender dan pengambilan keputusan di dalam keluarga. Menurut Muflikati (2010) menyatakan bahwa faktor yang paling berpengaruh terhadap kesejahteraan keluarga adalah keadaan ekonomi keluaga (pendapatan, pengeluaran, dan aset). Hasil penelitian yang dilakukan oleh Puspitawati, Herawati, dan Sarma (2010) juga menunjukkan bahwa kesejahteraan keluarga dapat memengaruhi fungsi keluarga. Tingkat kesejahteraan keluarga yang tinggi, berarti juga memiliki kualitas hidup yang baik, sehingga keluarga akan mampu menciptakan kondisi yang baik agar dapat meningkatkan kesejahteraan keluarga (Rosni, 2017).

Hasil analisis hubungan menemukan bahwa, semakin matang usia istri, maka kerja sama dalam melakukan pengambilan keputusan akan semakin menurun. Hal tersebut mungkin disebabkan oleh adanya faktor keputusan suami yang lebih dominan dalam pengambilan keputusan selama menjalani kehidupan rumah tangga (Mustika, et al., 2013). Selain itu, hasil juga menyebutkan bahwa, semakin tinggi pendidikan yang ditempuh oleh suami dan istri, maka semakin kerja sama yang harmoni dalam pembagian peran gender dan 
pengambilan keputusan dalam keluarga akan semakin terjalin. Hasil penelitian ini sejalan dengan penelitian yang dilakukan oleh Wilkening dan Bharadwaj (1968) bahwa tingkat pendidikan dapat memengaruhi pembagian tugas yang dilakukan oleh suami dan istri yang pada akhirnya akan memengaruhi keterlibatan dalam pengambilan keputusan. Selanjutnya, jika semakin besar pendapatan keluarga maka pengambilan keputusan di dalam keluarga cenderung dilakukan secara dominan di salah satu pihak antara istri atau suami. Hal ini sejalan dengan penelitian yang dilakukan oleh Astari, Hamid, dan Damayanti (2008) yang menyatakan bahwa proses pengambilan keputusan dipengaruhi oleh kondisi sosial ekonomi keluarga. Kemudian, hasil juga menunjukkan bahwa kontribusi ekonomi yang lebih besar oleh istri maka dalam melakukan pengambilan keputusan cenderung akan didominasi oleh salah satu pihak. Hal tersebut sejalan dengan penelitian yang dilakukan oleh Winkler (1998), bahwa istri yang menghasilkan pendapatan lebih besar dibandingkan suami, maka istri menjadi lebih dominan dalam melakukan pengambilan keputusan.

Hasil uji hubungan juga menemukan bahwa suami dan istri yang dapat berbagi peran dengan baik di dalam keluarga, maka pengambilan keputusan cenderung dilakukan secara bersama-sama oleh suami dan istri. Hal ini didukung oleh penelitian yang dilakukan oleh Challiol dan Mignonac (2005) bahwa peran gender dapat memengaruhi keterlibatan suami dan istri dalam pengambilan keputusan. Selain itu, semakin baik kerjasama yang dilakukan antara suami dan istri dalam melakukan pembagian peran, maka istri merasa semakin bahagia hidupnya. Semakin puas atau bahagia istri dengan keadaan hidupnya, maka kondisi kehidupan aktualnya juga semakin sejahtera

Hasil uji regresi menunjukkan bahwa peran gender pada domain domestik dan pendapatan keluarga berpengaruh positif dan signifikan terhadap kesejahteraan subjektif keluarga. Hal ini sejalan dengan penelitian yang dilakukan oleh Kusumo, Sunarti, dan Pranadji (2008) bahwa tingkat pendapatan per kapita berpengaruh positif terhadap tingkat kesejahteraan subjektif. Selain itu, jika istri semakin memprioritaskan keluarga (domesik) dibandingkan pekerjaan, maka cenderung meningkatkan kesejahteraan keluarga baik, fisik, sosial, maupun psikologis (Puspitawati \& Sari, 2008).

\section{SIMPULAN DAN SARAN}

Hasil penelitian menunjukkan bahwa usia suami dan istri termasuk ke dalam kelompok usia dewasa madya. Rata-rata keluarga contoh merupakan tipe keluarga kecil, yaitu keluarga yang terdiri dari empat orang dengan rata-rata pendapatan keluarga contoh sebesar Rp7.515.161,00. Melalui usaha mikronya, persentase terbesar istri berkontribusi terhadap pendapatan keluarganya sebesar 81 100 persen. Capaian tertinggi pembagian peran gender dilakukan secara seimbang dilakukan oleh suami-istri terdapat pada aktivitas sosial kemasyarakatan dan capaian terendah terdapat pada aktivitas domestik. Selain itu, capaian tertinggi pengambilan keputusan terdapat pada dimensi sosial budaya dan hubungan keluarga dan capaian terendah terdapat pada dimensi ekonomi. Kesejahteraan keluarga subjektif maupun kesejahteraan objektif keluarga contoh termasuk dalam kategori tinggi. Peningkatan pendapatan keluarga dan kerjasama peran gender dalam domain domestik secara konsisten berpengaruh positif dan signifikan terhadap peningkatan kesejahteraan subjektif keluarga dual earner dengan istri sebagai pelaku usaha ekonomi mikro di Jakarta dan memiliki suami yang bekerja di sektor formal dan informal.

Berdasarkan hasil penelitian terdapat beberapa saran yang dapat diberikan, yaitu keluarga sebaiknya menerapkan prinsip kerja sama gender, dalam melakukan pembagian peran dan pengambilan keputusan di dalam keluarga. Cara yang dapat dilakukan adalah suami dan istri saling bekerja sama dalam melakukan peran gender pada domain domestik, publik, dan sosial kemasyarakatan. Hal ini dilakukan agar tidak ada pihak antara suami atau istri yang lebih diberatkan dalam melaksanakan perannya. Selain itu, perlu ditingkatkan kembali strategi penyuluhan atau pemberdayaan keluarga terkait pentingnya penerapan pembagian peran gender yang harmoni di dalam keluarga, sehingga dapat memberikan pembekalan dan pemahaman tentang pentingnya peran gender antara suami dan istri untuk menjaga keseimbangan dalam menjalankan fungsi keluarga. Penyuluhan dapat dilakukan oleh kader-kader koperasi 
dibawah binaan LSM PPSW melalui pelatihanpelatihan yang dilakukan secara rutin. Pemeritah sebaiknya lebih memperhatikan usaha mikro, karena melalui usaha ini dapat dilakukan sebagai salah satu upaya dalam mengentaskan kemiskinan di Jakarta. Peneliti selanjutnya diharapkan dapat membuat pertanyaan yang lebih efektif dan efisien sehingga tidak mengganggu waktu bekerja responden dan memperkaya penelitian dengan mengukur kesejahteraan keluarga dari perspektif suami.

\section{DAFTAR PUSTAKA}

Astari, A. M., Hamid, A. Y. S., \& Damayanti, R. (2008). Studi kualitatif pengambilan keputusan dalam keluarga terkait dengan komplikasi perinatal di Kabupaten Cianjur Jawa Barat. Jurnal Kedokteran Brawijaya. 24(3).

[BPS] Badan Pusat Statistik. (2017). Tingkat Kemiskinan di DKI Jakarta September 2016 (Berita Resmi Statistik No. 04/01/31/Th.XIX, 03 Januari 2017). Diambil dari https://jakarta.bps.go.id/backend/brs_ind /brsind-20170103152330.pdf.

[BPS] Badan Pusat Statistik. (2015). Keadaan Ketenagakerjaan di DKI Jakarta Februari 2015 (Berita Resmi Statistik No.26/05/31/Th.XVI, 5 Mei 2015). Daimbil dari http://www.jakarta.go.id/v2/news/2015/0 5/keadaan-ketenagakerjaan-di-dkijakarta-februari-2015\#.WgMJmdOCzIU.

Delhey, J., Böhnke, P., Habich, R., \& Zapf, W. (2001). The eromodule a new instrument for comparative welfare research. Social Structure and Social Reporting. WZB Berlin Social Science Center, Berlin, Germany.

Dublin. (2013). Quality of life in Europe: Subjective well-being. European Foundation for the Improvement of Living and Working Conditions: Cornell University ILR Scholl. Doi: $10.2806 / 37878$.

Far, R. A. F. (2012). Peran gender dalam kehidupan rumah tangga di Desa Liang kabupaten Maluku Tengah, 1(1), 13-27

Hikmah, Yulisti, M., \& Nasution, Z. (2009). Pola pembagian kerja dan kontribusi gender terhadap pendapatan keluarga: studi kasus rumah tangga nelayan di Desa Batanjung Kabupaten Kapuas. Jurnal Bijak dan Riset Sosek KP, 4(1), 93-103.

Krzaklewska, E. (2014). Measurement of gender equality analyzing dimensions, embracing areas, considering contexts. Working paper no. 1.2 "Gender Equality and Quality of Life-State of Art Report", 1-33.

Kusmayadi, R. C. R. (2017). Kontribusi pekerja wanita dalam meningkatkan kesejahteraan keluarga dan proses pengambilan keputusan dalam keluarga (studi mengenai pekerja wanita dalam industry pengolahan tembakau PR. Tali Jagad di Desa Gondowangi Kecamatan Wangir Kabupaten Malang). Jurnal Ekonomi Syariah, 2(1),103-113

Kusumo, R. A. B., Sunarti, E., \& Pranadji, D. K. (2008). Analisis peran gender serta hubungannya dengan kesejahteraan keluarga petani dan holtikultura di daerah pinggiran perkotaan. Media Gizi dan Keluarga, 32(2), 52-64.

Lubis, N. L., \& Syahfitriani, E. (2007). Perbedaan konflik peran ganda suami ditinjau dari motivasi kerja kebutuhan ekonomi dan aktualisasi diri pada istri. Majalah Kedokteran Nusantara, 40(1), 512.

Marks, J., Bun, L. C., \& McHale, S. M. (2009). Family patterns of gender role attitudes. Sex Roles, 61(3-4), 221-234. Doi:10.1007/s11199-009-9619-3.

Martin, J. G. S., Balocnit, D. A., \& Venus, J. J. C. (2013). Household decision making patterns among Kalingas in Tabuk City. International Journal of Advanced Research in Management and Social Sciences, 2(8), 14-25.

Megawangi, R. (2014). Membarkan berbeda: sudut pandang baru tentang relasi gender. Depok, ID: Indonesia Heritage Foundation.

Muflikhati, I. (2010). Analisis dan pengembangan model peningkatan kualitas sumberdaya manusia dan kesejahteraan keluarga di wilayah pesisir Provinsi Jawa Barat (Disertasi). Institut Pertanian Bogor, Bogor, Indonesia. 
Munfaqiroh, S. (2016). Faktor yang mempengaruhi wirausaha wanita miskin untuk mencapai keberhasilan usaha. Jurnal JIBEKA, 10(1), 57-65.

Mustika, A., Rahmat T. A., \& Bahri, A. S. (2013). Pola pengambilan keputusan serta peran dan curahan kerja wanita dalam meningkatkan pendapatan rumah tangga di daerah tujuan wisata. Jurnal Ilmiah Pariwisata, 18(3), 231-245.

Peilow, F. J., \& Nursalim, M. (2013). Hubungan antara pengambilan keputusan dengan kematangan emosi dan self-efficacy pada remaja. Jurnal Fakultas IImu Pendidikan, 1(2), 1-6.

[PPSW] Pusat Pengembangan Sumber Daya Wanita. (2016). Diambil dari http://ppsw.or.id/index.php/profil-

kelompok/. [Dlunduh pada: 11 Desember 2016].

Puspitawati, H. (2012). Gender dan keluarga: konsep dan realita di Indonesia. Bogor, ID: IPB Press.

(2015). Pentingnya pendidikan keluarga berwawasan gender bagi Indonesia [kajian akademik]. Departemen IImu Keluarga dan Konsumen.

Puspitawati, H., Herawati, T., \& Sarma, M., (2010). Analisis gender terhadap strategi koping dan kesejahteraan keluarga. Jurnal Penelitian dan Pengembangan Kesejahteraan Sosial, 15(2), 138-151.

Puspitawati, H., \& Sari, E. P. M. (2008). Strategi penyeimbangan antara aktivitas pekerjaan dan keluarga pada wanita bekerja di Bogor, 1(2), 108-117.

Qoyyimah \& Wahini M. (2016). Faktor-faktor yang memengaruhi kesejahteraan keluarga di Desa Pucanglaban Kecamatan Pucanglaban Kabupaten Tulungagung. Jurnal Boga, 5(3), 63-72.

Rahmawaty, A. (2015). Harmoni dalam keluarga perempuan karir: upaya mewujudkan kesetaraan dan keadilan gender dalam keluarga. Palastren: Jurnal Studi Gender, 8(1), 1-34.

Rosni. (2017). Analisis tingkat kesejahteraan masyarakat nelayan di Desa Dahari Selebar Kecamatan Talawi Kabupaten Batubara. Jurnal Geografi, 9(1), 53-66.

Sultana, A. M., Hed, N., \& Leh, F. C. (2013). Woman's intra-household decision making and financial resources. Advances in Environmental Biology (p4703).

Twenge, J. M., Campbell, W. K., \& Foster, C. A. (2003). Parenthood and marital satisfaction: a meta-analytic review. Journal of Mariage and Family, 65(3), 574-583.

Wilkening, E. A., \& Bharadwaj L. K. (1968). Aspiration and task involvement as related to decision-making among farm husbands and wives. Rural Cociology, 33(1), 30-45.

Winkler, A. E. (1998). Earnings of husbands and wives in dual-earner families. Dual Earner Families. Monthly Labor Review. University of Missouri-St. Louis, 42-48. 